\begin{tabular}{|c|c|c|c|c|c|c|}
\hline \multirow{4}{*}{ Impact Factor: } & ISRA (India) & $=3.117$ & SIS (USA) & $=0.912$ & ICV (Poland) & $=6.630$ \\
\hline & ISI (Dubai, UAE & $=0.829$ & РИНЦ (Russia) & $=0.156$ & PIF (India) & $=1.940$ \\
\hline & GIF (Australia) & $=0.564$ & ESJI (KZ) & $=8.716$ & IBI (India) & $=4.260$ \\
\hline & JIF & $=1.500$ & SJIF (Morocco) & $=5.667$ & OAJI (USA) & $=0.350$ \\
\hline
\end{tabular}

\section{SOI: $1.1 /$ TAS $\quad$ DOI: $10.15863 /$ TAS International Scientific Journal Theoretical \& Applied Science}

p-ISSN: 2308-4944 (print) e-ISSN: 2409-0085 (online)

Year: 2019 Issue: $05 \quad$ Volume: 73

Published: $30.05 .2019 \quad$ http://T-Science.org
QR - Issue

QR - Article
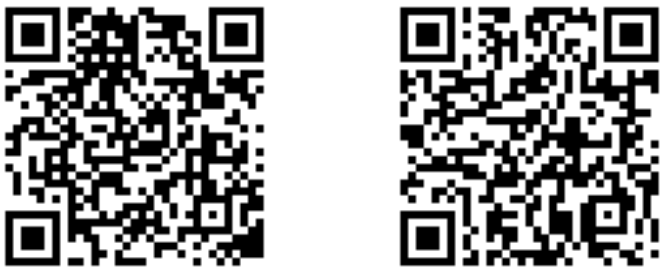

Zufar Akbarovich Nuriddinov

Tashkent Institute of Finance zufarnuriddinov@mail.ru

\title{
ECONOMETRIC MODELING OF INVESTMENT AND INNOVATION DEVELOPMENT OF THE REGIONS OF THE REPUBLIC OF UZBEKISTAN
}

Abstract: The article investigated the theoretical and practical issues related to the investment and innovative development of the regions of the Republic of Uzbekistan. Specifically, the country's economy has demonstrated a high level of investment and innovation in the economy, and the dependence of these indicators on the econometric model, and some recommendations have been developed.

Key words: investment, innovation, econometric modeling, panel data, fixed effect model, random effect model, innovative development.

Language: English

Citation: Nuriddinov, Z. A. (2019). Econometric modeling of investment and innovation development of the regions of the republic of Uzbekistan. ISJ Theoretical \& Applied Science, 05 (73), 426-431.

Soi: http://s-o-i.org/1.1/TAS-05-73-63 Doi: crossef https://dx.doi.org/10.15863/TAS.2019.05.73.63

\section{Introduction.}

In the current strategic economy, the role of economic and statistical analysis of the economy of the country, especially its regions, is very high. One clear example of this is the Decree of the President of the Republic of Uzbekistan on February 7, 2017 "On the Strategy for the Further Development of the Republic of Uzbekistan" and the August 8, 2017 "On Priority Measures to Ensure Rapid Social and Economic Development of the Regions" PQ-3182 are defined as priority directions for the issues of complex, proportional, socio-economic, investment and innovative development of regions, cities and towns [1].

Statistical and econometric analysis methods are widely used to assess the economy of the country and its regions. However, the methodological and organizational capabilities of this analysis are not being used effectively in the country, especially in the study of regional economies. This prevents their further socio-economic development. One of the most pressing problems of the present day is the transition to an innovative way of achieving competitiveness on the world market through technical and technological renewal of production, raising scientific expectations. Innovative approach requires development and application of new projects, investment, technical and technological renewal of production, structural transformation in the economy of the country. Particular attention is paid to the work on attraction of investments for the implementation of projects on structural transformation, modernization, technical and technological renovation of the country's economy.

\section{Materials and Methods}

Analyze of the above issues statistical analysis and econometrically model the following ideas, not their theory, but also statistical practice. Especially, to explore the investment and innovation environment in the country, including the prospects for their development.

The main results for statistical and econometric knowledge are the normative and analytical model of investment and innovation capacities in the regions. Hereinafter it can be seen at the share of investment in fixed capital in the regions of the country below. 


\begin{tabular}{|c|c|c|c|c|c|c|}
\hline \multirow{4}{*}{ Impact Factor: } & ISRA (India) & $=3.117$ & SIS (USA) & $=0.912$ & ICV (Poland) & $=6.630$ \\
\hline & ISI (Dubai, UAE & $=0.829$ & РИНЦ (Russia & $=0.156$ & PIF (India) & $=1.940$ \\
\hline & GIF (Australia) & $=0.564$ & ESJI (KZ) & $=8.716$ & IBI (India) & $=4.260$ \\
\hline & JIF & $=1.500$ & SJIF (Morocce & $=5.667$ & OAJI (USA) & $=0.350$ \\
\hline
\end{tabular}

Table 1. Share of regions into fixed capital investments in the Republic of Uzbekistan, in percentage

\begin{tabular}{|l|l|l|l|l|l|l|}
\hline Years & $\begin{array}{l}\text { Northern } \\
\text { Zone }\end{array}$ & $\begin{array}{l}\text { Western } \\
\text { Zone }\end{array}$ & $\begin{array}{l}\text { Southern } \\
\text { Zone }\end{array}$ & $\begin{array}{l}\text { Central } \\
\text { Region }\end{array}$ & $\begin{array}{l}\text { Eastern } \\
\text { Zone }\end{array}$ & $\begin{array}{l}\text { Republic of } \\
\text { Uzbekistan }\end{array}$ \\
\hline 2010 & 5,4 & 24,6 & 14,8 & 42,4 & 12,8 & 100 \\
\hline 2011 & 8,0 & 18,7 & 15,5 & 43,5 & 14,3 & 100 \\
\hline 2012 & 8,2 & 17,1 & 16,3 & 43,9 & 14,5 & 100 \\
\hline 2013 & 12,2 & 15,7 & 16,5 & 40,8 & 14,8 & 100 \\
\hline 2014 & 15,3 & 14,4 & 16,5 & 39,5 & 14,3 & 100 \\
\hline 2015 & 17,4 & 13,4 & 17,3 & 38,1 & 13,8 & 100 \\
\hline 2016 & 10,5 & 17,8 & 18,6 & 39,2 & 13,9 & 100 \\
\hline 2017 & 6,7 & 22,2 & 20,7 & 38,2 & 12,2 & 100 \\
\hline
\end{tabular}

*Source: Prepared by the author according to the statistics of The State Committee of the Republic of Uzbekistan on Statistics [2].

According to the table data, investments in fixed capital mainly accounted for in the central region, i.e. $40 \%$ in 2010-2013 and more than $38 \%$ in 2014-2017. The question is why investments in fixed capital are mainly attracted to the central part of the country. They need to be analyzed and analyzed statistically.

Integration of science and industry, cooperation between private entrepreneurs and the state, supporting international relations of small and medium-sized businesses are key prerequisites for the development of innovative activities. It should be noted that almost half of the innovations in the developed countries of the world are carried out by organizations and small and medium-sized businesses. In fact, according to the US National Science Foundation, the number of innovations implemented in smaller firms is much higher than the cost per unit of medium and large firms. In addition, smaller firms have accelerated innovation and deliver consumers approximately three-fold greater than the large firms [2].
Scientific and production integration processes will have a great impact when the university and technology institutes together with manufacturing companies and firms determine their share of patented development and undertake research and innovation projects. It is no coincidence that $85 \%$ of all international patents issued by the European Patent Office are in the same proportion.

It is noteworthy that in our country, the volume of innovative goods and services produced by the regions own power is growing year by year. However, it is desirable to consider the volume of innovative goodsand services produced by the regions own power by the shares in a country (Table 2 ).

As we can see from the table that in the research years the share of central and eastern regions is high in the formation of an innovative goods and services. Especially in recent years, the share of the central region relatively higher than other regions.

Table 2. Share of the volume of innovative goods and services produced by regions in the Republic of Uzbekistan,\%

\begin{tabular}{|l|l|l|l|l|l|l|}
\hline Years & $\begin{array}{l}\text { Northern } \\
\text { region }\end{array}$ & $\begin{array}{l}\text { Western } \\
\text { region }\end{array}$ & $\begin{array}{l}\text { Southern } \\
\text { region }\end{array}$ & Central region & $\begin{array}{l}\text { Eastern } \\
\text { region }\end{array}$ & $\begin{array}{l}\text { Republic of } \\
\text { Uzbekistan }\end{array}$ \\
\hline 2010 & 0,2 & 15,8 & 0,1 & 18,9 & 65,0 & 100 \\
\hline 2011 & 0,6 & 9,4 & 0,3 & 46,9 & 42,8 & 100 \\
\hline 2012 & 0,4 & 2,6 & 0,5 & 18,5 & 78,0 & 100 \\
\hline 2013 & 0,8 & 2,6 & 0,3 & 50,2 & 46,1 & 100 \\
\hline 2014 & 1,0 & 2,2 & 0,5 & 41,3 & 55,0 & 100 \\
\hline 2015 & 3,3 & 1,9 & 1,8 & 68,1 & 24,9 & 100 \\
\hline 2016 & 19,1 & 1,4 & 2,3 & 64,8 & 12,4 & 100 \\
\hline 2017 & 21,9 & 1,9 & 1,2 & 51,2 & 23,8 & 100 \\
\hline
\end{tabular}

Source: Prepared by the author according to the statistics of The State Committee of the Republic of Uzbekistan on Statistics.

World experience shows that in countries with developed innovative systems, innovation processes are effectively implemented, technology and other knowledge-intensive products are commercialized. The role of the state,the real sector of the economy and the leading companies supporting innovation 


\begin{tabular}{|c|c|c|c|c|c|c|}
\hline \multirow{4}{*}{ Impact Factor: } & ISRA (India) & $=3.117$ & SIS (USA) & $=0.912$ & ICV (Poland) & $=6.630$ \\
\hline & ISI (Dubai, UAE & $=0.829$ & РИНЦ (Russia & $=0.156$ & PIF (India) & $=1.940$ \\
\hline & GIF (Australia) & $=0.564$ & ESJI (KZ) & $=8.716$ & IBI (India) & $=4.260$ \\
\hline & JIF & $=1.500$ & SJIF (Morocce & $=5.667$ & OAJI (USA) & $=0.350$ \\
\hline
\end{tabular}

activities are essentialin this process. Science is the basis of this integration mechanism, which ensures the technical development of the state and socioeconomic growth of the society.

The main results of the researchaccording to the author's statistical analysis include: a regression model of Panel data regression models for the creation of the econometric model of analysis of investment attraction in the region is presented and the factors that have a major impact on the growth of the region's innovative products are studied.

Most models typically have one-dimensional structure. However, in practicewe often work with two dimensional economic data (structures). Meanwhile, one of the units of measurement belongs to the separate economic units, and the second one belongs to one or another period. Similarly, two-dimensional statistical bulletins appear in the course of observing a large number of objects over a specific period of time. Models based on two-dimensional data are called Panel data regression models in econometrics.

In addition, the followings can be seen as an example of sources of Panel data [3]:

- Observations of The Bureau of Labor Statistics of USA (National Longitudinal Surveys (NLS))[3];

- Observations of University of Michigan in USA(Panel Study of Income Dynamics (PSID))[4];

- Observations of Russian Longitudinal Monitoring Survey(HSE) [5].

The regression model of the Panel data regression models differs from time series regression or space regression. Its variables have two subindices:

$y_{i t}=\alpha+x_{i t}^{\prime} \beta+u_{i t} \quad[6]$

where $i$-track number of the observed item, $t-$ period of time, $\alpha$ is a scalar, $\beta$ - regression coefficients vector, $x_{i t}^{\prime}=\left(x_{1 i t}^{\prime}, x_{2 i t}^{\prime}, \ldots . x_{k i t}^{\prime}\right)$ the matrix vector of the variables.Often random error model with one component (builder) is used in Panel data:

$u_{i t}=f_{i}+\varepsilon_{i t}$

where $f_{i}$ - unforeseen individual effects, $\varepsilon_{i t}-$ residual random errors.

In this case, $f_{i}$ is not time-dependent and represents the characteristics (features) of objects that are not included in the regression equation.

In particular, two approaches are used to account for unobservable indirect effects of economic units [7].

The first is the fixed effect model (FE) $f_{i}$ individual effects, is considered as the unknown parameters of the model. This model needs to satisfy the following basic assumptions: regression;

- $x_{i t}^{\prime}$ row vector of a given values of

- $a_{i}$-a scalar;

- $\quad b$-column vector of regression coefficient;

- $\varepsilon_{i t}$-satisfies conditions of classical linear regression model, especially those that are not normally distributed and not correlated with $x_{i t}^{\prime}$ (constant variables).

$$
y_{i t}=x_{i t}^{\prime} b+a_{i}+\varepsilon_{i t}
$$

where $a_{i}$-scalars reflects unobservable variables representing individual characteristics over time.

The fixed effects model is expressed in the form of a matrix [4].

$y=x * b+z * A+\varepsilon$

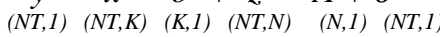

The Least - Squares Dummy Variable (LSDV)can be used to estimate the parameters of this model, so the following estimates are taken for the parameters:

$$
\hat{\beta}_{\mathrm{LSDV}}=\left(\begin{array}{c}
x^{\prime} x x \prime z \\
z^{\prime} x z^{\prime} z
\end{array}\right)^{-1}\left(\begin{array}{c}
x^{\prime} y \\
z^{\prime} y
\end{array}\right)
$$

In special literature, it is called the value of the smallest squares method, which is the fictitious (male, female) included in the regression equation.

Secondly, the random effect model (RE), $f_{i}$ is considered to be random numbers of the individual effects model and is not correlated with residual limits. The matrix look of this model is as follows:

$$
\begin{aligned}
& y=x * b+u \\
& (N T, 1)(N T, K) \quad(K, 1) \quad(N T, 1)
\end{aligned}
$$

In this case:

$$
\left\{\begin{array}{c}
u-\text { normal distributed } \\
x-\text { defined matrix } \\
E(u)=0, \text { because } E(u)=0, E(\varepsilon)=0 \\
E\left(u u^{\prime}\right)=\Omega \neq \sigma^{2} * I_{N T} \\
E\left(u_{i t} u_{i^{\prime} t}\right)=\delta_{i i^{\prime}} \sigma^{2}+\delta_{i t^{\prime}} \delta_{t t^{\prime}} \sigma_{\varepsilon}^{2}
\end{array}\right.
$$

where $\delta_{i t^{\prime}}=\left\{\begin{array}{l}1, i=i^{\prime} \\ 0, i \neq i^{\prime}\end{array}\right.$ Kronecker symbol.

If the above assumptions are fulfilled, the values obtained in the method of Generalized Least Squares (GLS)are ignored:

$$
\hat{b}_{G L S}=\left(x^{\prime} \Omega^{-1} x\right)^{-1} x^{\prime} \Omega^{-1} y
$$

Panel data can have different structures. For example, if the existing economic units are not lost for each time and new units do not appear, the Panel data is balanced, otherwise if the existing economic units are lost and not the same for each time and new units do appear then it is called unbalanced data. In unbalanced selection, various economic units are observed at different times. Such information is called counterfeit- Panel data [5].

Listed data processing is performed using the STATA packet (software).

First of all, we convert variables to natural logarithms.

The result symbol: $y($ the volume of produced innovative products)

$\ln ($ innovative product $)=\log ($ innovative product $)$

Factor: $\mathrm{x}_{1}$ (Expenses to innovation)

$\ln ($ Expenses to innovation $)=\log ($ Expenses to innovation)

Factor: $\mathrm{x}_{2}$ (investment in fixed capital)

$\ln$ (investment $)=\log$ (investment)

We will add regions as a separate factor to model, that is, create an alternative variable that will 


\begin{tabular}{|c|c|c|c|c|c|c|}
\hline \multirow{4}{*}{ Impact Factor: } & ISRA (India) & $=3.117$ & SIS (USA) & $=0.912$ & ICV (Poland) & $=6.630$ \\
\hline & ISI (Dubai, UAI & $=0.829$ & РИНЦ (Russia & $=0.156$ & PIF (India) & $=1.940$ \\
\hline & GIF (Australia) & $=0.564$ & ESJI (KZ) & $=8.716$ & IBI (India) & $=4.260$ \\
\hline & JIF & $=1.500$ & SJIF (Morocce & $=5.667$ & OAJI (USA) & $=0.350$ \\
\hline
\end{tabular}

represent the region and add it to the model, and use the STATA software to summarize the results of our model as followings.

1. Regression model. In(innovative product), $\ln ($ expenses to innovation), In(investment), eastern,central,

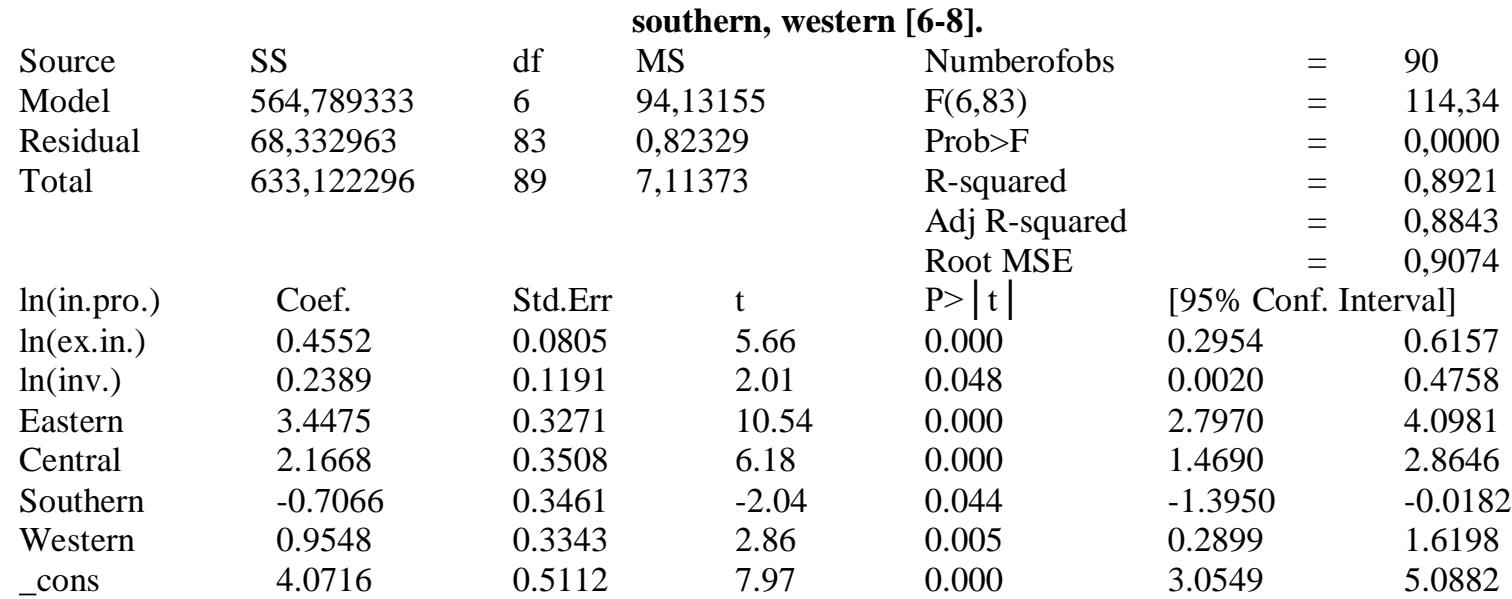

In the above regression equation, the positive impact of investment in fixed capital and expenses to innovation on thevolume of innovative product was determined. Both factors are statistically important at the $5 \%$ significance level $(\mathrm{P}>|\mathrm{t}|)$. According to the

model, the growth of investment by $1 \%$ will lead to an increase in the innovative product by $0.24 \%$. Increasing expenses to innovation by $1 \%$ leads to an increase in innovation productivity by average $0.46 \%$.

\section{Fixed effect model. $\ln ($ innovative product), $\ln ($ expenses to innovation), $\ln$ (investment).}

Fixed effect regression model

Group variable: id

R-sq: within $=0.6605$

between $=0.7889$

overall $=0.6321$

$\operatorname{corr}\left(u \_i, X b\right)=0.4213$

$\ln$ (in.pro.) Coef

$\ln ($ ex.in. $)$

$\ln$ (inv.)

_cons

sigma_u

sigma_e

rho

1.6671

0.9074

\author{
Numberofobs \\ Number of groups \\ Obs per group: min \\ avg \\ $\max$ \\ $\mathrm{F}(2,83)$ \\ Prob $>\mathrm{F}$
}

$\begin{array}{ll}= & 90 \\ = & 5 \\ = & 18 \\ = & 18.0 \\ = & 18 \\ = & 80.73 \\ = & 0.0000\end{array}$

Std.Err t

$0.0805 \quad 5.66$

$0.1191 \quad 2.01$

0.5215
$\mathrm{P}>|\mathrm{t}|$

0.000

0.048

0.000
$=$

0.0000

[95\% Conf. Interval]

$0.2954 \quad 0.6157$

$0.0020 \quad 0.4758$

$4.2068 \quad 6.2814$

F test that all $u_{-} \mathrm{i}=0$ :

0.7715 (fraction of variance due to $u \_i$ )

The Fixed Effects model, as well as the 1 st regression equation, the positive impact of investment in fixed capital and expenses to innovation on
$\mathrm{F}(4,83)=37.67$

thevolume of innovative product was determined. The other indicators are the same, ie the effect of the factors on the result.

3. Random effect model. In(innovative product), $\ln ($ expenses to innovation), $\ln ($ investment).

Random effect regression
Group variable: id
R-sq: within $=0.6602$
between $=0.7951$
$\quad$ overall $=0.6416$
corr $\left(\mathrm{u} \_\mathrm{i}, \mathrm{X}\right)=0$ (assumed)

Philadelphia, USA

$\begin{array}{lll}\text { Numberofobs } & = & 90 \\ \text { Number of groups } & = & 5 \\ \text { Obs per group: min } & = & 18 \\ \text { avg } & = & 18.0 \\ \text { max } & = & 18 \\ \text { Wald chi2(2) } & = & 165.36 \\ \text { Prob }>\text { chi2 } & = & 0.0000\end{array}$




\begin{tabular}{llllll} 
& ISRA (India) $=\mathbf{3 . 1 1 7}$ & SIS (USA) & $=\mathbf{0 . 9 1 2}$ & ICV (Poland) & $=\mathbf{6 . 6 3 0}$ \\
Impact Factor: & ISI (Dubai, UAE) $=\mathbf{0 . 8 2 9}$ & PUHL (Russia) $=\mathbf{0 . 1 5 6}$ & PIF (India) & $=\mathbf{1 . 9 4 0}$ \\
& GIF (Australia) $=\mathbf{0 . 5 6 4}$ & ESJI (KZ) & $=\mathbf{8 . 7 1 6}$ & IBI (India) & $=\mathbf{4 . 2 6 0}$ \\
& JIF & $\mathbf{1 . 5 0 0}$ & SJIF (Morocco) $=\mathbf{5 . 6 6 7}$ & OAJI (USA) & $\mathbf{0 . 3 5 0}$ \\
\hline
\end{tabular}

$\begin{array}{lllllll}\ln (\text { in.pro.) } & \text { Coef. } & \text { Std.Err } & \mathrm{z} & \mathrm{P}>|\mathrm{z}| & \text { [95\% Conf. Interval] } & \\ \ln (\text { ex.in.) } & 0.4819 & 0.0798 & 6.04 & 0.000 & 0.3256 & 0.6383 \\ \ln \text { (inv.) } & 0.2092 & 0.1188 & 1.76 & 0.078 & -0.0236 & 0.4419 \\ \text { _cons } & 5.2008 & 0.8257 & 6.30 & 0.000 & 3.5826 & 6.8191\end{array}$

$\begin{array}{ll}\text { sigma_u } & 1.4155 \\ \text { sigma_e } & 0.9074 \\ \text { rho } & 0.7088 \text { (fraction of variance due to u_i) }\end{array}$

F test that all $\mathrm{u}_{-} \mathrm{i}=0: \quad \mathrm{F}(4,83)=37.67 \quad$ Prob $>\mathrm{F}=0.0000$

The results of the Random Effect model also confirm the results of the Fixed Effect model, which also shows that the investment in fixed assets and the expenses to innovation have a positive effect on the volume of innovative product.The coefficients found are very close to thecoefficient of Fixed Effect model and the expenses oninnovation is at $1 \%$ and investments in fixed capital are statistically significant at the $10 \%$ significance level [9-14].

\begin{tabular}{|c|c|c|}
\hline & \multicolumn{2}{|c|}{$\begin{array}{l}\text { Breusch and Pagan Lagrangian multiplier test for random effects } \\
\text { Ln(innovative product) }[\mathrm{id}, \mathrm{t}]=\mathrm{Xb}+\mathrm{u}[\mathrm{id}]+\mathrm{e}[\mathrm{id}, \mathrm{t}]\end{array}$} \\
\hline Estimated results: & Var & $\operatorname{std}=\operatorname{sqrt}($ Var $)$ \\
\hline $\ln ($ in.pro.) & 7.1137 & 2.6672 \\
\hline e & 0.8233 & 0.9074 \\
\hline $\mathrm{u}$ & 2.0036 & 1.4155 \\
\hline Test: & $\begin{array}{l}\operatorname{Var}(u)=0 \\
\text { Chibar2 }(01)=16029 \\
\text { Prob }>\text { chibar } 2=0.0000\end{array}$ & \\
\hline
\end{tabular}

The results of the Breusch and Pagan test above indicate that the Random Effect model can be used for that information.

\section{Conclusion.}

Based on the Panel data, the following conclusions were drawn:

- Many objects are observed, resulting in an increase in the number of independent levels and improving the effectiveness of selection value;
- Eliminates aggregate shifts that may appear unwillingly when analyzing time series as well as space data;

- Creating Opportunity to monitor the dynamics of different objects;

- Analysis of many important economic issues will be possible.

\section{References:}

1. (n.d.). website of the National Database of Legislation of the Republic of Uzbekistan. Retrieved 2019, from www.lex.uz

2. (n.d.). website of The State Committee of the Republic of Uzbekistan on Statistics. Retrieved 2019, from www.stat.uz

3. (n.d.). United State Bureau of labor statistics. Retrieved 2019, from www.bls.gov

4. (n.d.). PSID - University of Michigan Retrieved 2019, from www.psidonline.isr.umich.edu

5. (n.d.). UNC Carolina Population Center. Retrieved 2019, from www.cpc.unc.edu
6. Yeleseyeva, I. I. (2007). "Econometrics" Textbook. Moscow: Finance and statistics.

7. Damodar, N. G. (2004). "Basic Econometrics" fourth edition.

8. (2017). The Decree of the President of the Republic of Uzbekistan "On the Strategy for the Further Development of the Republic of Uzbekistan". "Xalq so'zi" newspaper.// 08.02.2017 . №28 (6722).

9. Shermukhamedov, O. A. (n.d.). Selection and Estimation of Personnel for Banking System/ In 


\begin{tabular}{|c|c|c|c|c|c|c|}
\hline \multirow{4}{*}{ Impact Factor: } & ISRA (India) & $=3.117$ & SIS (USA) & $=0.912$ & ICV (Poland) & $=6.630$ \\
\hline & ISI (Dubai, UAE & $=0.829$ & РИНЦ (Russia & $=0.156$ & PIF (India) & $=1.940$ \\
\hline & GIF (Australia) & $=0.564$ & ESJI (KZ) & $=8.716$ & IBI (India) & $=4.260$ \\
\hline & JIF & $=1.500$ & SJIF (Morocce & $=5.667$ & OAJI (USA) & $=0.350$ \\
\hline
\end{tabular}

the 10 th KALM International Conference "Shared Value for Business and Economic

10. (2012). Partnership in the Asian Countries, 18 May, 2012. / Hanyang University Business School, Republic of Korea, pp.98-100.

11. Shermukhamedov, O. A. (2011). Method of assessment in the evaluation of effectiveness of the quality of employees of the banking system. Proc. Uzbek-Indonesian Joint International Conference "Economics and management towards nation character development" Jakarta, 18-19 October 2011. (pp.78-81). Jakarta: Publish House Gunadarma University, Indonesia.

12. Shermukhamedov, O. A. (2011). Estimation of the human capital in condition of the modernizations of the economy. Proc. UzbekIndonesian Joint International Conference "Economics and management towards nation character development" Jakarta, 18-19 October 2011. Jakarta: Publish House Gunadarma University, Indonesia.

13. Shermukhamedov, O. A. (2011). The problems of social protection in Uzbekistan. Proc. UzbekIndonesian Joint International Conference "Economics and management towards nation character development" Jakarta, 18-19 October 2011. (pp.121-124). Jakarta: Publish House Gunadarma University, Indonesia.

14. Shermukhamedov, O. A. (2010). Labor organization level at the light industry of the republic of Uzbekistan and the directions of its increase. Proceedings of the $7^{\text {th }}$ International Joint Conference, Kumoh National Inst. of Technology, Gumi, Korea. (pp.101-104). Gumi, Republic Korea, Kumoh National Inst. of Technology. 